\title{
Early evidence of trepanation along the Yellow River Basin in Neolithic China
}

\author{
Yawei Zhou ${ }^{1}$. Shuang Lin ${ }^{1} \cdot$ Wanfa Gu${ }^{2} \cdot$ Letian $\mathrm{He}^{3} \cdot$ Qun Zhang $^{4}$ (D) $\cdot$ Hui-Yuan Yeh $^{4}$
}

Received: 20 February 2020 / Accepted: 8 July 2020 / Published online: 20 July 2020

(C) The Author(s) 2020

\begin{abstract}
Trepanation is a long-lasting ancient practice found around the world with diverse motivations. However, the distribution and motivation of intentional trepanation in China remain unclear. This study presents one of the earliest trepanations on a male adult individual who is unearthed from the Shuanghuaishu site in Gongyi, Henan, dating back to the late Yangshao cultural period (3500-2900 BC). The macroscopic and microscopic observation, alongside with micro-CT scan, are conducted to further evaluate the conditions on the edges of the perforation and intracranial situation. The oval perforation is located on the occipital bone, and neither fracture nor apparent healing signs are observed on the margins. Archeological evidences and simulated experiment indicate that the trepanation could be conducted by drilling the tables of the skull with a V-bladed stone tool. In view of the location of the perforation and the limited details on the edges, the motivation behind the trepanation could be due to the medical treatment of trauma on the occipital bone or a postmortem ritual. The analysis of the early trepanation along the Yellow River Basin provides further evidence on the ancient human behavior and enriches our understanding of the origin and distribution of trepanation in Neolithic China.
\end{abstract}

Keywords Trepanation $\cdot$ Shuanghuaishu site $\cdot$ Neolithic $\cdot$ Medical treatment $\cdot$ Ritual $\cdot$ China

\section{Introduction}

Trepanation is a worldwide ancient practice which refers to the perforation on the skull. It was first discovered and identified by Paul Broca and Ephraim George Squier in the 1860s (Broca 1867a, 1867b; Clower and Finger 2001; Finger and Fernando 2001; Arnott et al. 2003; Verano and Finger 2010).

Letian $\mathrm{He}$

helt@1zu.edu.cn

Qun Zhang

zhang.qun@ntu.edu.sg

Hui-Yuan Yeh

hyyeh@ntu.edu.sg

1 History College, Zhengzhou University, 100 Science Ave., Zhengzhou 450001, Henan, China

2 Zhengzhou Municipal Institute of Cultural Relics and Archaeology, 31 Jianshe Rd, Zhengzhou 450052, Henan, China

3 School of History and Culture, Lanzhou University, 222 Tianshui S Rd, Lanzhou 730020, Gansu, China

4 School of Humanities, Nanyang Technological University, 48 Nanyang Ave, Singapore 639818, Singapore
It has been practiced throughout human history from the Neolithic period to the modern era. Moreover, trepanation has been found all over the world, such as in Europe (Piggott 1940; Mariani-Costantini et al. 2000; Facchini et al. 2003; Weber and Wahl 2006; Lopez et al. 2011; Nicklisch et al. 2018; Tulumello et al. 2018; Pasini et al. 2019; Piombino-Mascali et al. 2019), Asia (Zias and Pomeranz 1992; Sankhyan and Weber 2001; Bazarsad 2003; Han and Chen 2007; Han et al. 2007; Lv et al. 2013; Khudaverdyan 2016; Zhang et al. 2018; Reddy and Satyamurthy 2019), America (Tello 1913; Powell 1970; Jørgensen 1988; Stone and Miles 1990; Velasco-Suarez et al. 1992; Andrushko and Verano 2008; Verano 2016a; Kushner et al. 2018), Africa (Margetts 1967; Nerlich et al. 2003; Collado-Vázquez and Carrillo 2014), and Oceania (Houghton 1977; Vasilyev and Sviridov 2017). Anthropological and ethnographic evidences demonstrated several motivations for trepanation including post-injury treatment or postmortem rituals (Capasso and Tota 1996; Han and Chen 2007; Moskalenko et al. 2008). Aufderheide et al. (1998) further propose the three main reasons for ancient trepanation: therapeutic, cultural, and symbolical. Therapeutic trepanation is performed as a surgery for cranial traumas and diseases, including fracture, mastoiditis, 
meningioma, osteomyelitis, epidural infection, and leprosy (Jørgensen 1988; Zias and Pomeranz 1992; Smrčka et al. 2003; Andrushko and Verano 2008; Khudaverdyan 2011; Petrone et al. 2015), while cultural and symbolic trepanations are attributed to the religious, ritualistic, or magical motivations (Jordanov et al. 1988; Gresky et al. 2016). Based on anthropological studies and medical historical records, several different techniques are adapted to conduct this ancient practice including scraping, grooving, drilling, cutting, and sawing (Freeman 1918; Popham 1954; Lisowski 1967; Campillo 1984; Rifkinson-Mann 1988; Piek et al. 1999; Weber and Czarnetzki 2001).

Currently, in China, over 100 cases related to ante-/postmortem trepanation have been reported in Xinjiang, Heilongiiang, Henan, Qinghai, and Gansu, since the first discovery in the Inner Mongolia in 1941 (Han and Chen 2007; Han et al. 2007; Ye 2012; Lv et al. 2013; Hobert and Binello 2017; Zhang et al. 2018). According to sporadic reports, trepanation is widely distributed in northern China. The earliest recognized and wellhealed trepanation is found in east China in Fujia site of Shandong Guangrao dating back to the Middle Dawenkou Culture period (3500-2800 BC) (Han et al. 2007). In northwestern China, trepanations are found in Yangshan site of Qinghai Minhe and Liuwan site of Qinghai Ledu, dating back to the late Neolithic period (Han et al. 2007). In Mogou site of Gansu Lintan, nine well-healed trepanned skulls are found to be related to cultural rituals (Dittmar et al. 2019). In Bietebasitao site of Xinjiang, trepanation with clear-cut marks is found to be related to therapeutic purposes (Zhang et al. 2018). It has been proved that trepanation is conducted in ancient China and had been present for more than 2000 years from the Neolithic period to the Iron Age period (Han et al. 2007; Han and Chen 2007; Ye 2012; Hobert and Binello 2017; Zhang et al. 2018). However, the identification and motivation of trepanation are still under debate. In March 2019, a skeleton with occipital trepanation is found in the Shuanghuaishu site dating back to the Neolithic Yangshao cultural period in the middle reaches of the Yellow River Basin in central China. The whole skeleton is sited in a normal anatomical position, and the perforation is located right in the center of the occipital sagittal plane. The aim of the present study is to report one of the earliest cases of trepanation along the Yellow River Basin in central China and thereby contributes to the understanding of this worldwide phenomenon, as well as its origins and distribution during the early times in China.

\section{Materials and methods}

The Shuanghuaishu site (N $34^{\circ} 81^{\prime} 45^{\prime \prime}$, E $\left.113^{\circ} 09^{\prime} 29^{\prime \prime}\right)$ is located on the tableland south of Shuanghuaishu Village in Heluo Town, Gongyi City, Henan Province (Fig. 1). The area of the site is 1.17 million square meters with large-scale cemeteries distributed in an orderly fashion (Fig. 2). Since the end of

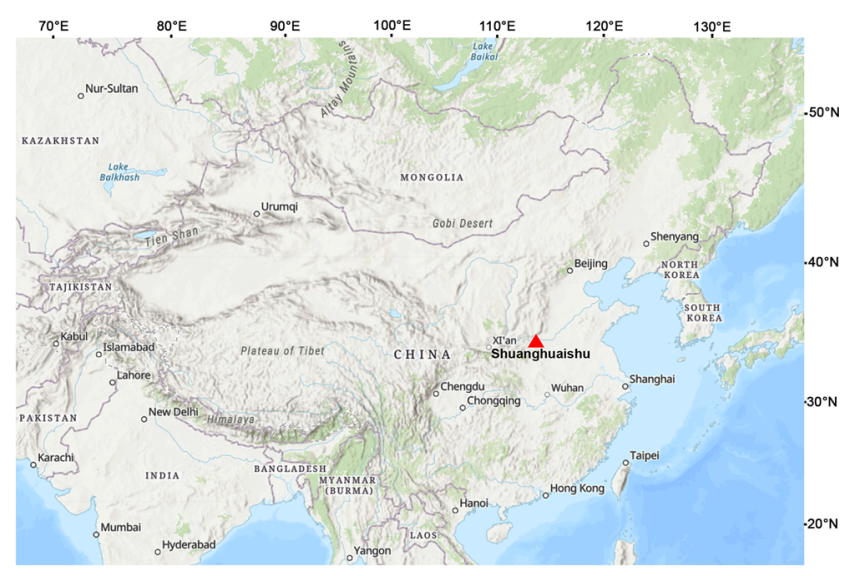

Fig. 1 Location of the Shuanghuaishu site (marked in red star) and the distribution of trepanation in China (Neolithic case marked in star and the Bronze Age and Iron Age cases marked in triangle)

2013, over 1600 tombs have been excavated, and 287 sets of human skeletons have been obtained. This site is the largest cemetery during the late Yangshao cultural period (35002900 BC) in the Central Plains of China. In addition, the triple trench found at the site is the largest and deepest defensive facility discovered during that period. Tomb M487 is a single primary burial, which is unearthed from the central area of the inner loop of the triple trench at the site. The skeleton is west oriented in an extended position with no buried grave goods. The skeleton is poorly preserved except for the relatively intact skull.

The sex and age of the individual are determined based on the skeletal remains using its cranium and postcranial characteristics (Brooks and Suchey 1990; Buikstra and Ubelaker 1994). The cranium is examined using various scientific techniques. Macroscopic observation focuses on the shape, dimensions, location, and pathological conditions on the bone, whereas microscopic observation focuses on the edges of the perforation. Details of the trepanation are observed using a Dino-Lite Digital Microscope (magnification 20-30 times) and a three-dimensional deep-field microscope (VHX-2000 series, Keyence, Japan) (magnification 50-100 times). In addition, a high-resolution industrial computed tomography scan (450 kV-ICT; made by the Institute of High Energy Physics, Chinese Academy of Sciences) is conducted to obtain bone radiopacity in order to differentiate new bone formation and to obtain intracranial situation. The scan data are processed by using the software created by the Institute of High Energy Physics, Chinese Academy of Sciences and Mimics 19 (Materialise, Leuven, Belgium).

\section{Results}

The individual of M487 is a male between the ages of 35 and 50 years old. The perforation on the occipital bone is oval in 
Fig. 2 a The Shuanghuaishu site; b the skeleton onsite; $\mathbf{c}$ layout of the skeleton
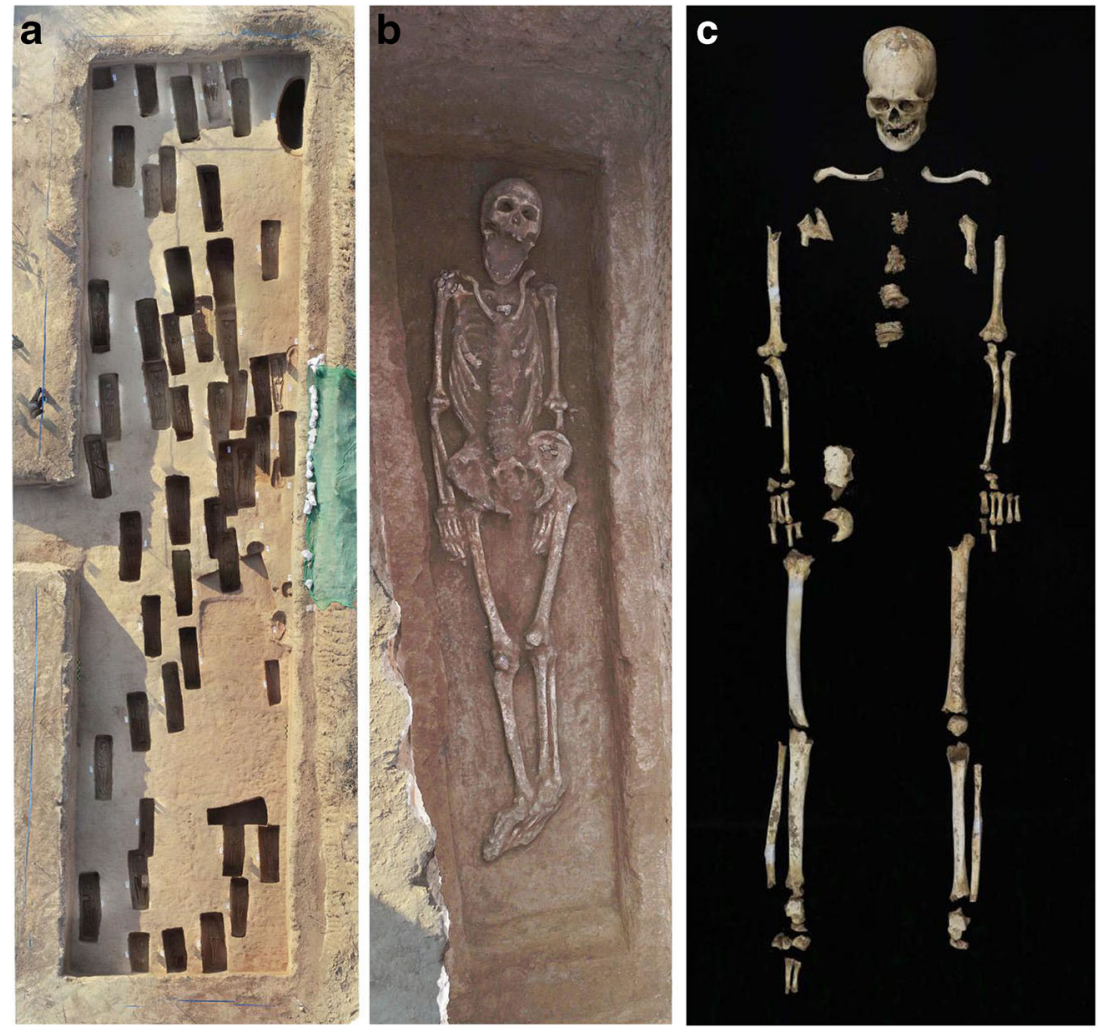

shape. The dimensions of the perforation are $12.51 \mathrm{~mm}$ by $10.07 \mathrm{~mm}$, with an area of approximately $219.82 \mathrm{~mm}^{2}$. The perforation is close to the mastoid processes and the asterion on both sides as listed in Table 1 . It is almost exactly on the sagittal plane of the occipital. The microscopic observation shows that the edges of the perforation are sharp and distinct, without marks left behind by scraping or cutting. Neither fracture nor apparent healing signs are observed on the margins (Fig. 3). Based on the CT scan, a three-dimensional reconstruction shows that the perforation is located in the middle and posterior part of the superior sagittal sinus and cranial inner table beveling could be observed around the perforation. CT images show that there is no highly radiolucent bone reconstruction at the margins, demonstrating that no formation of new bone occurred (Fig. 4). Considering that the tomb is undisturbed based on the original burial and the normal anatomical position of the skeleton, we can conclude that trepanation is probably performed immediately before or after the death of the individual.

\section{Discussions}

\section{Differential diagnosis}

The perforation on the skull could be attributed to several reasons (Aufderheide et al. 1998; Steinbock 1976; Kaufman et al. 1997; Ortner 2003; Petrone et al. 2015; Verano 2016b). Trauma, pathological defect, and postmortem damage could lead to the perforations on the skull which could be mistaken for trepanation. Comminuted fractures caused by blunt force injuries and penetrating injuries are common types of skeletal trauma that are easily confused with trepanation in archeological contexts. Comminuted fractures are caused by low-velocity blunt implements and characterized by multiple fragments with irregular rims and fracture lines (Verano 2016a). Penetrating injuries are the result of the highvelocity projectile implements which typically leave characteristic entrance and exit wounds on the bone (Verano 2016a). The shape and size of the wound are consistent with use of

Table 1 Measurements of the perforation on the occipital bone (unit: $\mathrm{mm}$ )

\begin{tabular}{lllll}
\hline Circumference & $\begin{array}{l}\text { Distance to the left } \\
\text { mastoid process }\end{array}$ & $\begin{array}{l}\text { Distance to the right } \\
\text { mastoid process }\end{array}$ & $\begin{array}{l}\text { Distance to } \\
\text { the inion }\end{array}$ & $\begin{array}{l}\text { Distance to the } \\
\text { left asterion }\end{array}$ \\
\hline 57.25 & 102.59 & 102.24 & 18.26 & $\begin{array}{l}\text { Distance to the } \\
\text { right asterion } \\
\text { lambda }\end{array}$ \\
\hline
\end{tabular}


Fig. 3 a Posterior view of the trepanned skull; $\mathbf{b}$ closeup of the perforation; $\mathbf{c}$ the smooth margin of the perforation with no apparent cut mark; $\mathbf{d}$ no bone defect around the perforation

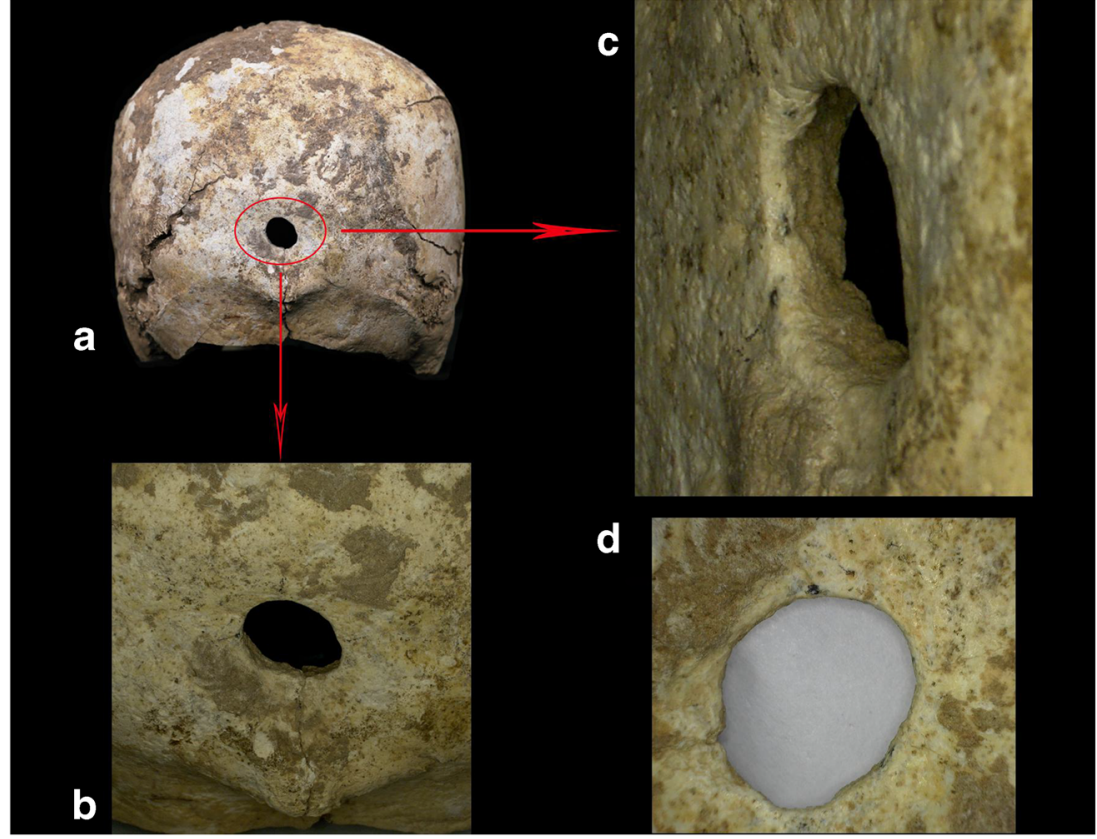

weapons with sharp edges, radial fracture lines, and internal beveling at the entry. Pathological defects with lytic lesions, destructive and irregular margins caused by cranial dysostosis, pyogenic bacteria, tuberculosis, treponemal disease, metastatic carcinoma, multiple myeloma, and bone neoplasm could be misdiagnosed as trepanations as well (Kaufman et al. 1997; Ortner 2003). Postmortem damage to the crania can be created by the breakage, erosion, weathering, and gnawing marks by carnivores and rodents (Verano 2016a).

In the current case, neither fragmental deformation nor radial fractures are observed around the occipital perforation, which is not consistent with the characteristics of trauma. In some circumstances, such kind of perforation without fracture line on the occipital could be formed by using a hard, sharp, and pointed implement at a high velocity (Smith et al. 2015; Forsom and Smith 2017; Jordana et al. 2009). However, in the Neolithic China, only small sharpened stone tools with limited penetrative ability have been unearthed so far (Fig. 5). Due to the location and the thickness of the occipital bone, it is usually difficult to penetrate the cranium in one attempt without causing visible damages to the surrounding bones with such stone tools. The clearly defined edge without any lytic lesion or destructive margin differentiates it from being due to pathological defects or postmortem damages. All this evidence indicates that the perforation on the occipital was created by intentional trepanation.
Fig. 4 CT reconstruction of the skull (ectocranial and endocranial view of the cranium)

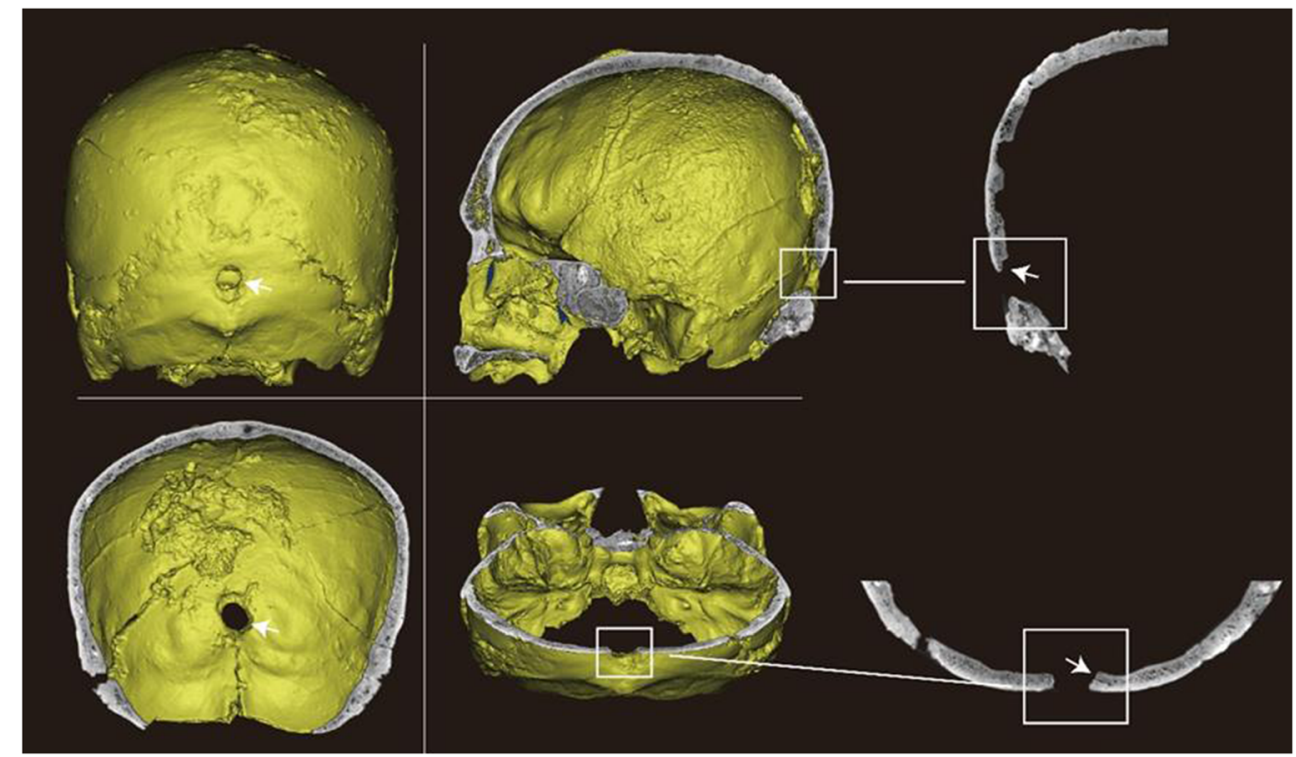


Fig. 5 a Experimental simulation of the trepanation on the maxillary of the pig skull; b sharpened stone tool found at Shuanghuaishu site; c endocranial view of the experimental trepanation on the pig skull

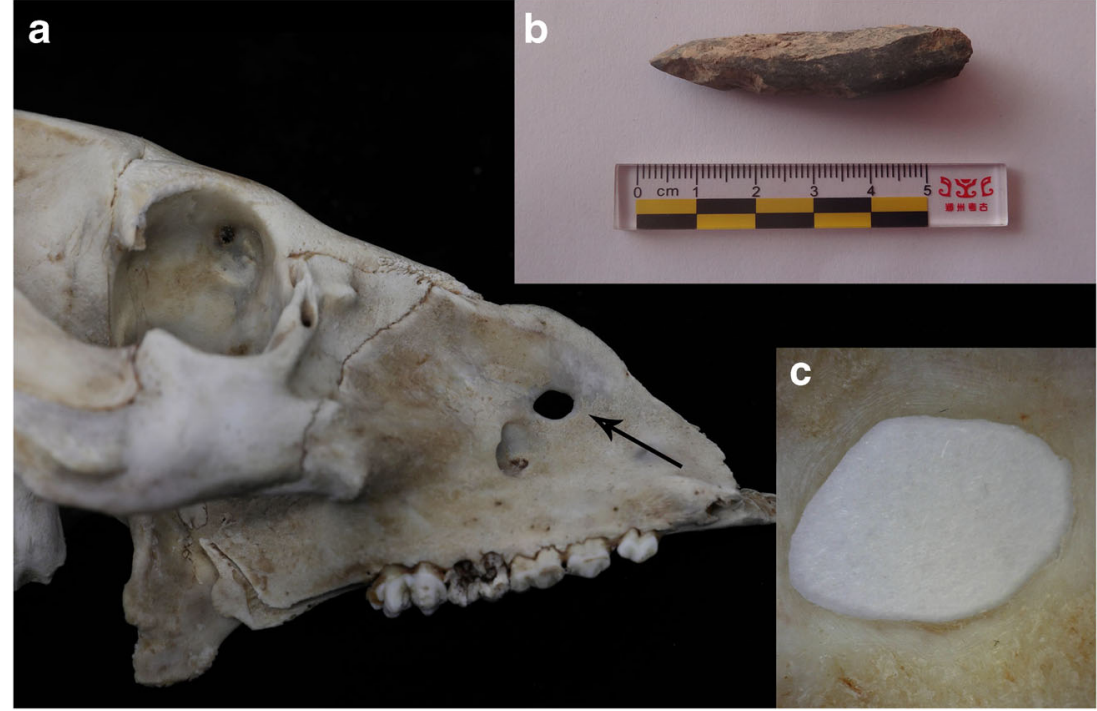

\section{Method and tool of the trepanation}

Based on prior studies on trepanation, it is generally categorized into five commonly used techniques when conducting the practice (Campillo 1984; Arnot et al. 2003). (1) Drilling refers to drilling with a hard sharp stone or implement to produce a perforation with neat edges. The size of the perforation depends on the sharpness and the size of the implement used. (2) Grooving refers to the circumscribing of a circular or oval portion of bone from the tables of the skull by repeated cutting with an incisive instrument until a disc of bone can be removed. In common cases, obvious marks left by the sharp implement can be observed on the edges of the perforation. (3) Scraping refers to the abrasing of the outer table, diploe, and the inner table by a hard abrasive implement until the meninges are exposed. The perforation caused by this method can be identified by a slight slope surrounding it, alongside an incomplete and powdery bone that is scraped off. (4) Intersecting linear cutting, also known as the "Indian canoe" style, refers to the cutting of four intersecting straight lines into the plate and the subsequent removal of the middle square piece. It is first found in Peru and is very popular in South America. (5) Boring and cutting refer to drilling of a circle of tightly connected small holes. Subsequently, cutting the bone bridges between them allows the removal of a disc of bone. This method will leave the plate in a slightly gear shape, and only one example is found in the Chaiwobu cemetery in Xinjiang, China. Notably, scraping is the most common method practiced in prehistoric times, while the cases related to linear cutting and boring and cutting techniques are extremely rare (Lisowski 1967; Campillo 2007). However, it should be noted that in trepanations with well-healed bones, the specific marks left behind may be obscured by bone remodeling on the edges of the perforation (Lastres and Cabieses 1960). However, no consensus has been reached yet regarding the implements used in the practice of trepanation. From the Neolithic period to the modern era, the implement varies in different regions, periods, and cultural contexts.

On the current trepanned skull, although considering the taphonomic effect on the bone, neither cut marks by sharp objects nor a slope by scraping is observed around the perforation. The perforation is oval in shape, which differentiates it from the regular circle created by grooving or linear marks by cutting. To further reconstruct the method of trepanation, the skull of a domestic pig is selected to simulate the trepanning process. Since only tools made of stone and bone are used in the Neolithic China, sharp flints or sharpened animal bones and antlers are believed to be used for drilling and cutting. In the experiment, trepanation is conducted on the maxillary of the pig skull by using a tool with a $\mathrm{V}$-shaped blade to drill and polish the edges of the perforation. A regular circle could be obtained by using a symmetrical V-shaped tool, while an oval perforation which is similar to the one on the human skull is obtained by using an asymmetrical V-shaped tool (Fig. 5). Therefore, it is assumed that the oval perforation on the skull could be drilled by a primitive stone tool with an asymmetrical V-shaped blade (Fig. 6).

\section{The motivation of the trepanation}

The motivations behind the trepanation are diverse, such as for therapeutic, cultural, and symbolical purposes (Aufderheide et al. 1998). To begin, trepanation for medical purposes aim to treat the trauma on the head or some refractory head diseases caused by mastoiditis, meningioma, osteomyelitis, epilepsy, mental disorder, intracranial tumor, and leprosy (Jørgensen 1988; Smrčka et al. 2003; Andrushko and Verano 2008; Khudaverdyan 2011; Petrone et al. 2015; Facchini et al. 2003; Verano 2003; Erdal and Erdal 2011; Zhang 2018). For example, trepanations accompanied with 


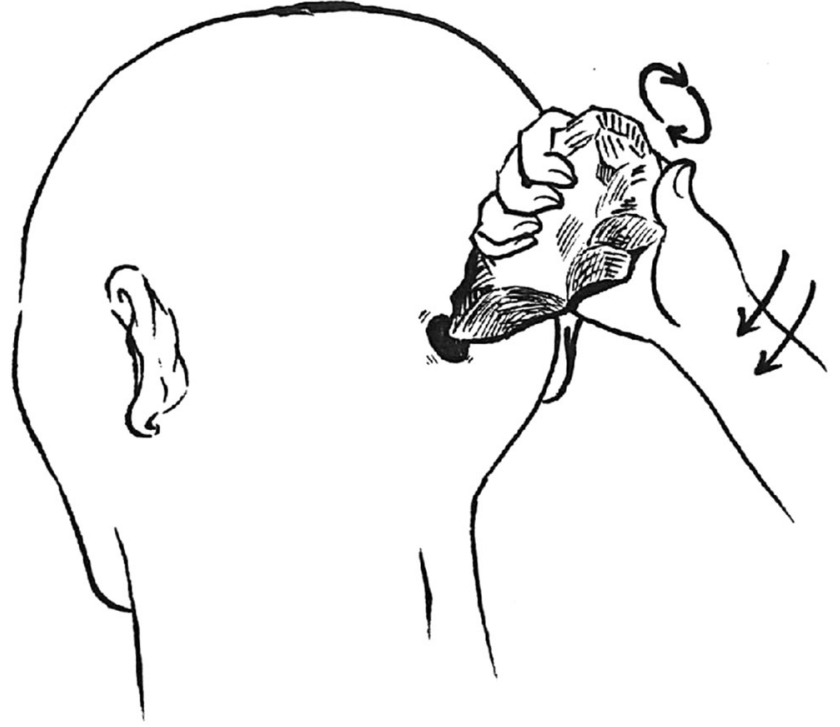

Fig. 6 Schematic diagram of the simulated perforation process

trauma on the head are found in many regions as a treatment to relieve intracranial pressure from extradural hemorrhage that is caused by an external force (Petrone et al. 2015; Zhang et al. 2018). Through observing the locations of the previous trepanned skulls, it is noted that the left parietal is the most common location for the trauma treatment due to its vulnerability during conflicts and interpersonal violence (Verano 2003; Han et al. 2007). Besides, among therapeutic trepanations from Europe and Peru, the forehead and left parietal are the most common locations, indicating that these locations are intentionally chosen to avoid the locations where the vital veins are distributed (Verano 2003). For cultural purposes, trepanation is always related to religious, ritual, or magical powers. For instance, bone discs, obtained by trepanation on the dead, are made into amulets that are worn by people for exorcism or purposes of blessing (Ruffer 1919; Oakley et al. 1959; Oeftinger and Wahl 2000; Claridge and Fabian 2005; Lv et al. 2013). Generally, grooving is commonly used when intercepting the bone disc, which would leave visibly obvious cut marks around the perforation. Symbolic trepanation refers to an incomplete trepanation in some cultural contexts wherein a belief in immortal souls prevails. Trepanation is performed to facilitate the soul of the dead to be released out of the body while keeping the inner table intact (Boev 1965; Jordanov et al. 1988; Ramseier et al. 2005; Gresky et al. 2016). In some prehistoric tribes with worship of skulls, skulls are even trepanned and hung for ritual purposes (Liu 1999). In the Altai stone burials and the Saka population who lives in the steppe of middle Asia, trepanation is performed to extract the brain and to preserve the body (Liu 1999).

To determine the motivation of trepanation, it is essential to distinguish whether the perforation is performed ante-mortem, peri-mortem, or postmortem. A perforation without signs of healing indicates that it could have been performed perimortem or postmortem. In the current case, the perforation is observed in a special location of the skull, without any cut marks or signs of polishing, fracture, or pathological conditions. It is located right on the posterior and superior section of the superior sagittal sinus vein, which is precisely in the middle (Fig. 7). The superior sagittal sinus is connected to the important venous reflux of the external part of the brain, which is fatal when damaged. In view of this, two motivations could be hypothesized. One hypothesis is that this trepanation was performed for medical treatment when the individual is still alive. The trepanation is performed on the wound to relieve hematoma but failed due to

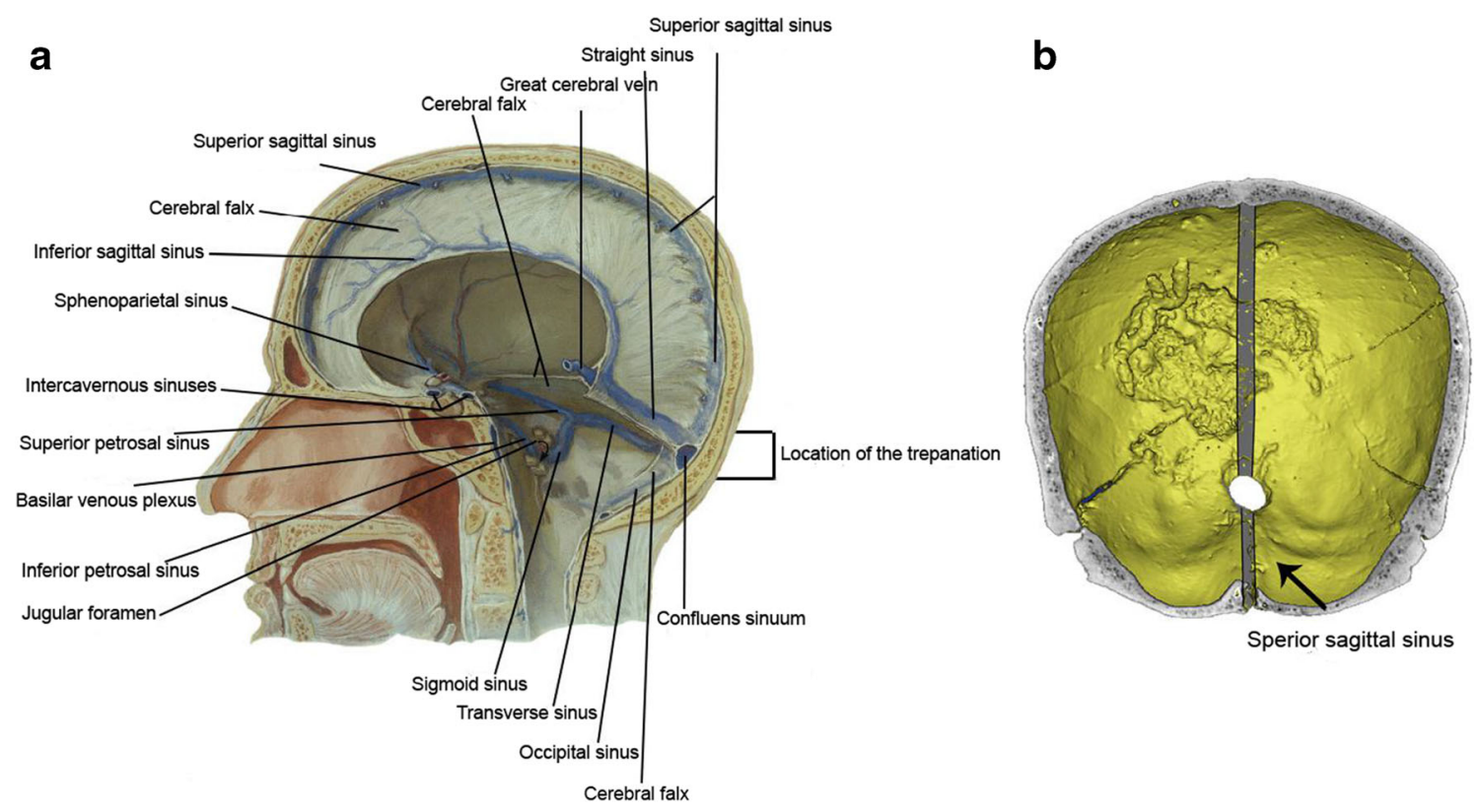

Fig. 7 Illustration of the sagittal sinus. a Head anatomy along the sagittal plane. b CT reconstruction of the endocranial situation 
the unusual and dangerous location of the trepanation. Another hypothesis is that it could be a postmortem ritual practice. There is no solid evidence to support it being a symbolic trepanation, especially when it is a single case among nearly 300 sets of skeletons unearthed from the cemetery. However, we should not exclude the possibility of it having a ritualistic or magical motivation. The trepanation could have been performed on the special location for a particular ritualistic purpose.

\section{Conclusion}

Though there are abundant researches on ancient trepanation, the origins and distribution of the practice are still a controversial issue. The Neolithic trepanation found in the Shuanghuaishu site is one of the earliest cases along the Yellow River Basin in central China. Multidisciplinary analyses reveal that the perforation on the occipital bone is a result of intentional trepanation, as it is without any signs of cut marks or healing. Archeological evidence and simulated experiment indicate that the trepanation could be conducted by drilling the cranial bone plate with a Vbladed stone tool. In light of the location of the perforation and the limited details on the edges, the motivations behind the practice could be related to medical treatment of the trauma on the occipital bone or a postmortem ritual. More individuals with trepanation might have been discovered in the cemetery, if not for the poor preservation of skeletons in that particular environment. Nevertheless, this research not only significantly provides one of the earliest evidence of trepanation in China but also contributes to further illuminate the origin and distribution of this ancient practice in China.

Funding information This research is supported by the NAP Start-Up Grant from Nanyang Technological University; the research on the roots of Chinese civilization of Zhengzhou University (Grant No. XKZDJC202006); the sub-project of the Major Project of the National Social Science Fund of China (Grant No. 19ZDA227): the research and analysis of the archeological data from Shuanghuaishu site in Gongyi, Henan (2013-2018); the Youth Project of the National Social Sciences Fund of China (Grant No. 17CKG021); the sub-project of the Central Plains Civilization Exploration Project in Henan Province (Grant No. 24220078); the 57th batch of the China Postdoctoral Science Fund (Grant No. 2015 M572113); and the open research project of the Key Laboratory of the Ministry of Education of Cultural Heritage Research and Protection Technology of Northwestern University (Grant No. xbdx2019-5-18).

\section{Compliance with ethical standards}

Conflict of interest The authors declare that they have no conflict of interest.

Open Access This article is licensed under a Creative Commons Attribution 4.0 International License, which permits use, sharing, adaptation, distribution and reproduction in any medium or format, as long as you give appropriate credit to the original author(s) and the source, provide a link to the Creative Commons licence, and indicate if changes were made. The images or other third party material in this article are included in the article's Creative Commons licence, unless indicated otherwise in a credit line to the material. If material is not included in the article's Creative Commons licence and your intended use is not permitted by statutory regulation or exceeds the permitted use, you will need to obtain permission directly from the copyright holder. To view a copy of this licence, visit http://creativecommons.org/licenses/by/4.0/.

\section{References}

Andrushko VA, Verano JW (2008) Prehistoric trepanation in the Cuzco region of Peru: a view into an ancient Andean practice. Am J Phys Anthropol 137:4-13

Arnott R, Finger S, Smith C (2003) Trepanation. CRC Press, London

Aufderheide AC, Rodríguez-Martín C, Langsjoen O (1998) The Cambridge encyclopedia of human paleopathology (Vol. 478). Cambridge University press, Cambridge

Bazarsad N (2003) Four cases of trepanation from Mongolia, showing surgical variation. In: Arnott R, Finger S, Smith CUM (eds) Trepanation history, discovery. Theory. Swets \& Zeitlinger Publishers, Lisse, pp 203-208

Boev P (1965) Symbolische Trepanationen in der UdSSR. Berichte des morph Inst der Bulg Akad der Wissenschaften (Sofia) 19:113-127

Broca P (1867a) Cas singulier de trepanation chez les Incas. Société d'Anthropologie de Paris 2:403-408

Broca P (1867b) Trepanation chez les Incas. Bulletin de l'Académie Nationale de Médicine (Paris) 32:866-872

Brooks S, Suchey JM (1990) Skeletal age determination based on the os pubis: a comparison of the Acsádi-Nemeskéri and Suchey-Brooks methods. Hum Evol 5:227-238

Buikstra JE, Ubelaker DH (1994) Standards for data collection from human skeletal remains. Arkansas archaeological survey report number 44: Arkansas: Fayetteville

Campillo D (1984) Neurosurgical pathology in prehistory. Acta Neurochir 70:275-290

Campillo D (2007) La Trepanación Prehistórica. Edicions Bellaterra, Barcelona

Capasso L, Tota GD (1996) Possible therapy for headaches in ancient times. Int J Osteoarchaeol 6:316-319

Claridge JA, Fabian TC (2005) History and development of evidencebased medicine. World J Surg 29:547-553

Clower WT, Finger S (2001) Discovering trepanation: the contribution of Paul Broca. Neurosurgery 49(6):1417-1426

Collado-Vázquez S, Carrillo JM (2014) Cranial trepanation in the Egyptian. Neurologia 29:433-440. https://doi.org/10.1016/j.nrl. 2011.05.012

Dittmar JM, Zhan XY, Berger E, Mao RL, Wang H, Zhao YS, Yeh HY (2019) Ritualistic cranial surgery in the Qijia Culture (2300-1500 BC), Gansu, China. Acta Anthropologica Sinica 38(3):389-397

Erdal YS, Erdal ÖD (2011) A review of trepanations in Anatolia with new cases. Int J Osteoarchaeol 21(5):505-534

Facchini F, Rastelli E, Ferrero L, Fulcheri E (2003) Cranial trepanation in two skulls of early medieval Italy. Homo 53:247-254

Finger S, Fernando HR (2001) E. George Squier and the discovery of cranial trepanation: a landmark in the history of surgery and ancient medicine. J Hist Med Allied Sci 56:353-381

Forsom E, Smith MJ (2017) Getting to the point: an experimental approach to improving the identification of penetrating projectile trauma to bone caused by medieval arrows. J Archaeol Sci Rep 11:274 286

Freeman L (1918) Primitive surgery of the Western hemisphere. J Am Med Assoc 70:443-448 
Gresky J, Batieva E, Kitova A, Kalmykov A, Belinskiy A, Reinhold S, Berezina N (2016) New cases of trepanations from the 5th to 3rd millennia BC in Southern Russia in the context of previous research: possible evidence for a ritually motivated tradition of cranial surgery? Am J Phys Anthropol 160:665-682

Han K, Chen X (2007) The archaeological evidence of trepanation in early China. Bulletin of the Indo-Pacific Prehistory Association 27:22-27

Han K, Tan J, He C (2007) Trepanation in ancient China. Fudan University Press, Shanghai

Hobert L, Binello E (2017) Trepanation in ancient China. World Neurosurg 101:451-456

Houghton P (1977) Trephination in Oceania. J Polyn Soc 86:265-269

Jordana X, Galtés I, Turbat T, Batsukh D, García C, Isidro A, Giscard PH, Malgosa A (2009) The warriors of the steppes: osteological evidence of warfare and violence from Pazyryk tumuli in the Mongolian Altai. J Archaeol Sci 36(7):1319-1327

Jordanov J, Dimitrova B, Nikolov S (1988) Symbolic trepanations of skulls from the Middle Ages (9th-10th century) in Bulgaria. Acta Neurochir 92:15-18

Jørgensen J (1988) Trepanation as a therapeutic measure in ancient (preInka) Peru. Acta Neurochir 93:3-5

Kaufman MH, Whitaker D, McTavish J (1997) Differential diagnosis of holes in the calvarium: application of modern clinical data to palaeopathology. J Archaeol Sci 24(3):193-218

Khudaverdyan AY (2011) The anthropology of infectious diseases of Bronze Age and Early Iron Age from Armenia. Dental Anthropology 2:42-54

Khudaverdyan AY (2016) Trepanation in the Late Bronze Age and Early Iron Age in Armenia. Homo 67:447-461

Kushner DS, Verano JW, Titelbaum AR (2018) Trepanation procedures/ outcomes: comparison of prehistoric Peru with other ancient, medieval, and American civil war cranial surgery. World Neurosurg 114: 245-251. https://doi.org/10.1016/j.wneu.2018.03.143

Lastres JB, Cabieses F (1960) La Trepanación Del Cráneo En El Antiguo Perú. Universidad Nacional Mayor de San Marcos, Lima

Lisowski FP (1967) Prehistoric and early historic trepanation. In: Brothwell DR, Sandison AT (eds) Diseases in antiquity. Charles C Thomas, Springfield, pp 651-672

Liu XT (1999) Trial analysis on prehistoric trepanning in Xinjiang. N.W minorities research 1:43-55

Lopez B, Caro L, Pardinas AF (2011) Evidence of trepanations in a medieval population (13th-14th century) of northern Spain (Gormaz, Soria). Anthropol Sci 119:247-257

Lv XL, Li ZG, Li YX (2013) Prehistoric skull trepanation in China. World Neurosurg 80(6):897-899

Margetts EL (1967) Trepanation of the skull by the medicine-men of primitive cultures, with particular reference to present-day native East African practice. In: Brothwell DR, Sandison AT (eds) Diseases in antiquity. Charles C Thomas, Springfield, IL, pp 673701

Mariani-Costantini R, Catalano P, di Gennaro F, di Tota G, Angeletti LR (2000) New light on cranial surgery in ancient Rome. Lancet 355: 305-307

Moskalenko YE, Weinstein GB, Kravchenko TI, Mozhaev SV, Semernya VN, Feilding A, Halvorson P, Medvedev SV (2008) The effect of craniotomy on the intracranial hemodynamics and cerebrospinal fluid dynamics in humans. Fizlogiya Cheloveka 34: $41-48$

Nerlich AG, Zink A, Szeimies U, Hagedorn HG, Rösing FW (2003) Perforating skull trauma in ancient Egypt and evidence for early neurosurgical therapy. In: Arnott R, Finger S, Smith CUM (eds) Trepanation history, discovery. Theory. Swets \& Zeitlinger Publishers, Lisse, pp 191-202

Nicklisch N, Dresely V, Orschiedt J, Ramsthaler F, Schlenker B, Ganslmeier R, Friederich S, Meller H, Alt KW (2018) A possible case of symbolic trepanation in Neolithic Central Germany. Int J Osteoarchaeol 28(3):216-226

Oakley KP, Brooke WM, Akester AR, Brothwell D (1959) Contributions on trepanning or trephination in ancient and modern times. Man:9396

Oeftinger C, Wahl J (2000) Eine schnurkeramische Zierscheibe aus menschlichem Schädelknochen-Versuch einer Interpretation. Fundberichte aus Baden-Württemberg 24:177-190

Ortner DJ (2003) Identification of pathological conditions in human skeletal remains. Academic Press, San Diego

Pasini A, Donati R, Bramanti B, Salzani L, Gualdi-Russo E (2019) New evidence of prehistoric neurosurgery in Italy: the case of Castello Del Tartaro. World Neurosurg 128:556-561. https://doi.org/10. 1016/j.wneu.2019.05.096

Petrone P, Niola M, Di Lorenzo P, Paternoster M, Graziano V, Quaremba G, Buccelli C (2015) Early medical skull surgery for treatment of post-traumatic osteomyelitis 5,000 years ago. PLoS One 10(5): e0124790

Piek J, Lidke G, Terberger T, von Smekal U, Gaab MR (1999) Stone age skull surgery in Mecklenburg-Vorpommern: a systematic study. Neurosurgery 45:147-151

Piggott S (1940) A trepanned skull of the Beaker period from Dorset and the practice of trepanning in prehistoric Europe. Proceedings of the Prehistoric Society 6:112-132

Piombino-Mascali D, Juškys R, Longo M, Loynes R (2019) The trepanned skull from Comiso (Ragusa): trauma, surgery, and care in Modern Age Sicily. J Forensic Radiol Imaging 19:100342. https:// doi.org/10.1016/j.jofri.2019.100342

Popham RE (1954) Trepanation as a rational procedure in primitive surgery. Univ Tor Med J 31:204-211

Powell BW (1970) Aboriginal trephination: case from southern New England? Science 170:732-734

Ramseier F, Hotz G, Meyer L (2005) Ur-und frühgeschichtliche Schädeltrepanationen der Schweiz: Vom Neolithikum bis ins Mittelalter. Bulletin der Schweizerischen Gesellschaft für Anthropologie 11(1-2):1-58

Reddy DR, Satyamurthy T (2019) Cranial trepanation in ancient India. Neurol India 67(3):639-642. https://doi.org/10.4103/0028-3886. 263227

Rifkinson-Mann S (1988) Cranial surgery in ancient Peru. Neurosurgery 23:411-416

Ruffer A (1919) Studies in palæopathology. Some recent researches on prehistoric trephining J Pathol Bacteriol 22:90-104

Sankhyan AR, Weber GH (2001) Evidence of surgery in Ancient India: trepanation at Burzahom (Kashmir) over 4000 years ago. Int J Osteoarchaeol 11:375-380

Smith MJ, James S, Pover T, Ball N, Barnetson V, Foster B, Guy C, Rickman J, Walton V (2015) Fantastic plastic? Experimental evaluation of polyurethane bone substitutes as proxies for human bone in trauma simulations. Legal Med 17(5):427-435

Smrčka V, Kuželka V, Melková J (2003) Meningioma probable reason for trephination. Int J Osteoarchaeol 13:325-330

Steinbock RT (1976) Paleopathological diagnosis and interpretation: bone diseases in ancient human populations. Charles $\mathrm{C}$ Thomas Pub Limited, Springfield, Illinois

Stone JL, Miles ML (1990) Skull trepanation among the early Indians of Canada and the United States. Neurosurgery 26:1015-1020

Tello JC (1913) Prehistoric trephining among the Jauyos of Peru. International Congress of Americanists, Proceedings of the XVIII Session, 1912. Harrison and Sons, London, pp 75-83

Tulumello G, Riccomi G, Minozzi S, Longo S, Longo M, Giuffra V (2018) Linear cutting trepanation in Italy: a unique case from Hellenistic Sicily (third century BC). World Neurosurg 116:116120. https://doi.org/10.1016/j.wneu.2018.05.058 
Vasilyev SV, Sviridov AA (2017) Trepanation and enlarged parietal foramen on skulls from the Loyalty Islands (Melanesia). Acta Med Hist Adriat 15:67-72

Velasco-Suarez M, Martinez JB, Oliveros RG, Weinstein PR (1992) Archaeological origins of cranial surgery: trephination in Mexico. Neurosurgery 31:313-319

Verano JW (2003) Trepanation in prehistoric South America: geographic and temporal trends over 2,000 years. In: Arnott R, Finger S, Smith CUM (eds) Trepanation history, discovery. Theory. Swets \& Zeitlinger Publishers, Lisse, pp 223-236

Verano JW (2016a) Differential diagnosis: trepanation. Int J Paleopathol $14: 1-9$

Verano JW (2016b) Holes in the head: the art and archaeology of trepanation in ancient Peru. Dumbarton Oaks Research Library and Collection

Verano JW, Finger S (2010) Ancient trepanation. In: Aminoff MJ (ed) Handbook of clinical neurology. Elsevier, Amsterdam, pp 3-14
Weber J, Czarnetzki A (2001) Trepanations from the early medieval period of southwestern Germany-indications, complications and outcome. Zentralbl Neurochir 62:10-14

Weber J, Wahl J (2006) Neurosurgical aspects of trepanations from Neolithic times. Int J Osteoarchaeol 16:536-545

Ye Y (2012) Trepanation in Xinjiang archaeology. Master dissertation, Minzu University of China

Zhang Q, Wang Q, Kong B, Wang C, Yang D, Zhu H, Zhang Q (2018) A scientific analysis of cranial trepanation from an Early Iron Age cemetery on the ancient Silk Road in Xinjiang, China. Archaeol Anthropol Sci 10:1319-1327

Zias J, Pomeranz S (1992) Serial craniectomies for intracranial infection 5.5 millennia ago. Int J Osteoarchaeol 2:183-186

Publisher's note Springer Nature remains neutral with regard to jurisdictional claims in published maps and institutional affiliations. 